\title{
Guidelines for Return to Presential Classes: Consensus Proposal in Accordance with the National and International Health Regulatory Agencies
}

\author{
Toufic Anbar Neto, Denise Daher Anbar, Isabela Daher Anbar, João Pedro Daher Anbar, \\ Idiberto José Zotarelli Filho*
}

FACERES, Medical School of Sao Jose do Rio Preto, Jardim Francisco Fernandes, São José do Rio Preto, Brazil

Email: *dr.idibertozotarelli@faceres.com.br

How to cite this paper: Neto, T. A., Anbar, D. D., Anbar, I. D., Anbar, J. P. D., \& Filho, I. J. Z. (2020). Guidelines for Return to Presential Classes: Consensus Proposal in Accordance with the National and International Health Regulatory Agencies. Creative Education, 11, 2627-2638.

https://doi.org/10.4236/ce.2020.1112195

Received: October 26, 2020

Accepted: December 12, 2020

Published: December 15, 2020

Copyright (c) 2020 by author(s) and Scientific Research Publishing Inc. This work is licensed under the Creative Commons Attribution International License (CC BY 4.0).

http://creativecommons.org/licenses/by/4.0/

\begin{abstract}
Introduction: The coronavirus disease pandemic (COVID-19) caused an unprecedented crisis in the area of education, causing the massive closure of classroom activities by educational institutions in more than 190 countries. By mid-May 2020, more than 1.2 billion students at all levels of education worldwide have stopped taking face-to-face classes. Therefore, the reopening of schools, colleges, and universities during the COVID-19 pandemic represents a special challenge worldwide in order to ensure the safety of students and staff. The guidelines need to outline the creation of a task force at each university, risk screening based on school, travel history, occupation, contacts, groups, and self-management. Objective: In this way, the present work had as objective to propose a guideline of return to the face-to-face classes based on the main regulatory criteria of government agencies in Brazil and the world. Methods: The present study followed a review model of the main national and international public health legislation as UNESCO, WHO and ANVISA. Development and Strategies: According to the process of economic reopening in Brazil and the world, the return to educational activities begins with the effective need to develop an action plan inherent to this resumption, gradually and safely. The resumption requires several strategic measures adopted by the executive powers of all spheres of power (federal, state and municipal), allowing at that moment the safe, but gradual, resumption of economic activity, reducing the harmful and collateral effects in terms of social inequality. Conclusion: Multiple intervention strategies at the school and reductions in transmission in the community, in addition to the extent achieved so far, will be necessary to avoid the excessive undue risk associated with the
\end{abstract}


reopening of the school.

\section{Keywords}

Education, Face to Face Classes, Legislation, Monitoring, COVID-19

\section{Introduction}

The coronavirus disease pandemic (COVID-19) caused an unprecedented crisis in the area of education, causing the massive closure of classroom activities by educational institutions in more than 190 countries, to prevent the spread of the virus and mitigate its impact. According to data from the United Nations Educational, Scientific and Cultural Organization (UNESCO), by mid-May 2020, more than 1.2 billion students at all levels of education worldwide have stopped taking face-to-face classes. Of these, more than 160 million were students in Latin America and the Caribbean (UNESCO, 2020).

When entering the recovery phase of COVID-19, it will be essential to reflect on the role of educational systems and, particularly vocational education, in promoting resilient societies (WHO \& UNICEF, 2020). The global health crisis and the ensuing blockade brought an unprecedented challenge to the professions, renewing awareness of its value to society. It also helped to restore a sense of esteem for those workers who struggled tirelessly during this time to maintain savings (WHO, 2020).

In this scenario, the pandemic exposed global vulnerability to crises and revealed how precarious and interdependent economies can be. It also resulted in natural diseases, political, economic and environmental disorder. Our ability to respond effectively and efficiently in the future will depend on government forecasting, readiness and preparedness (WHO, 2020).

Through their role in developing the competencies and skills needed for tomorrow's society, education systems will need to be at the center of this planning (ANVISA, 2020). This includes rethinking how the economy should evolve to protect itself against adversity, and defining the skills, education and training needed. This also means working closely with other sectors of the government and the private sector to increase the attractiveness and prospects of the labor market for certain professions, including those considered essential for the common good (ANVISA, 2020).

The real change usually occurs in deep crises, and at this moment it keeps the possibility of not going back to the status quo when things are back to "normal". Although this crisis has profoundly disruptive implications, including for education, it has no predetermined results. It will be the nature of the collective and systemic responses to these disruptions that will determine how we are affected by them (Brasil (SAPS), 2020).

In this sense, the pandemic is also a call to renew the commitment to sustainable development goals, ensuring that all young people have the opportunity to 
succeed in school and develop their knowledge, skills, attitudes and values. The current crisis has tested man's ability to deal with large-scale disruptions. As a corollary, it is imperative to build a more resilient society (Brasil, 2020).

Therefore, the reopening of schools, colleges and universities during the COVID19 pandemic represents a special challenge worldwide to ensure the safety of students and staff. The guidelines need to outline the creation of a task force at each university, risk screening based on the school, travel history, occupation, contacts and groups. Also, health self-management and quarantine measures, general hygiene measures (including the use of masks in indoor environments), principles of ventilation and sanitation, regulations on school assemblies, notification of suspicious cases and policies on closing schools and school classes replacement. Also, a class should be suspended if 1 student or employee tests positive and the school should be closed for 14 days if it has 2 or more confirmed cases (Cheng, Wang, Shen, \& Chang, 2020).

In this way, the present work had as objective to propose a guideline of return to the face-to-face classes based on the main regulatory criteria of government agencies in Brazil and the world.

\section{Methods}

\subsection{Study Design}

The present study followed a review model of the main national and international public health legislation. After literary search criteria using the MeSH Terms that were cited in the item below on "Search strategies", a total of 35 official documents from Brazi (ANVISA), WHO (World Health Organization) and scientific articles were submitted to the eligibility analysis and, after that, 16 documents were selected.

\subsection{Search Strategy and Information Sources}

The search strategy was carried out in the databases PubMed, Embase, Ovid and Cochrane Library, Web Of Science, ScienceDirect Journals, Scopus, UNESCO, WHO and ANVISA website. MeSH Terms: Education. Face to face classes. Legislation. Monitoring. COVID -19, and use of "and" Booleans between MeSH terms and "or" among historical findings.

\section{Development and Strategies}

\subsection{Guidelines for Gradual Return to Activities}

$\checkmark$ Controlled transmission of the virus.

$\checkmark$ National health system with the capacity to detect, test, isolate, treat, and monitor the contagion network.

$\checkmark$ Risk of outbreak minimized.

$\checkmark$ Preventive measures are implemented in workplaces, schools, and places where the movement of people is essential.

$\checkmark$ Risk of "importing" the virus under control. 
Society fully educated, engaged, and empowered to join new norms of social interaction.

$\checkmark$ The decision of the appropriate time to reopen, in each location, is up to public authorities.

\subsection{How to Return?}

Figure 1 represents the main strategies according to the regulatory bodies in Brazil and the world, establishing several axes of decision making that are regulated by the Public Health Emergency Operations Center Network (EOC-NET) (WHO \& UNICEF, 2020; WHO, 2020; ANVISA, 2020).

According to the process of economic reopening in Brazil and the world, the return to educational activities begins with the effective need to develop an action plan inherent to this resumption, gradually and safely, without prejudice to preventive and preventive measures. combating the COVID-19 pandemic. The resumption requires several strategic measures adopted by the executive powers of all spheres of power (federal, state and municipal), allowing at that moment the safe, but gradual, resumption of economic activity, reducing the harmful and collateral effects in terms of social inequality (Johns Hopkins University, 2020).

Also, the compatibility of these measures with the guidelines of the World Health Organization (WHO), the Ministry of Health (Brazil), and the regional and local health authorities about the response plan to COVID-19 and the biosafety guidelines and rules to be imposed for the gradual resumption of economic and educational activities (WHO, 2020; Brasil, 2010).

Besides, because Brazilian private institutions serve around 15 million students, being structured and built with investments from families, regulated and evaluated by governmental structures, it is essential to partner families not only in the formal education of their children, but as a structure of support so that fathers and mothers can develop their professional activities, promote their livelihood, especially when the more than 9 million students served in basic education are highlighted, with 2.5 million in early childhood education (Brasil, 2020).

In this scenario, it is essential to balance the variables involved, including seeking to ensure the safety of children in the school environment, following health and care protocols to avoid contagion with other children and adults. Thus, based on several government and private plans to resume face-to-face activities of schools and universities in Brazil and the world, a strategic plan for gradual and safe resumption is proposed. As an antecedent phase, it is necessary to follow the rules presented in Table 1 (WHO \& UNICEF, 2020; WHO, 2020; Brasil, 2020).

\section{Proposal for a General Protocol}

Table 2 presents the proposals for a general protocol WHO \& UNICEF, 2020; WHO, 2020; Brasil, 2020; Brasil (n 5), 2020).

Figure 2 schematically represents the local monitoring action plan, as a possible model. 


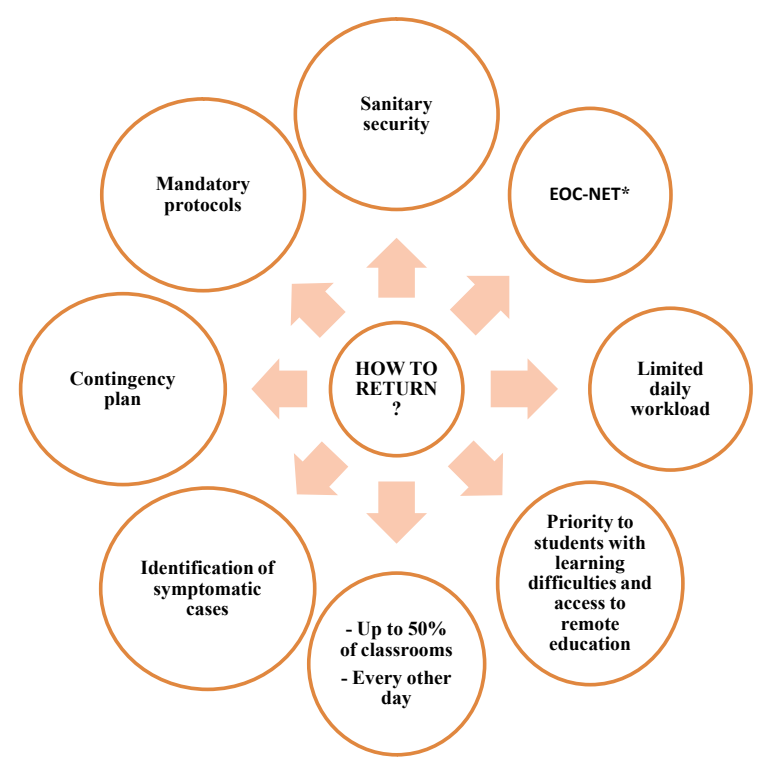

Figure 1. Main strategies for returning to face-to-face classes. ${ }^{\star}$ Public Health Emergency Operations Centre Network (EOC-NET).

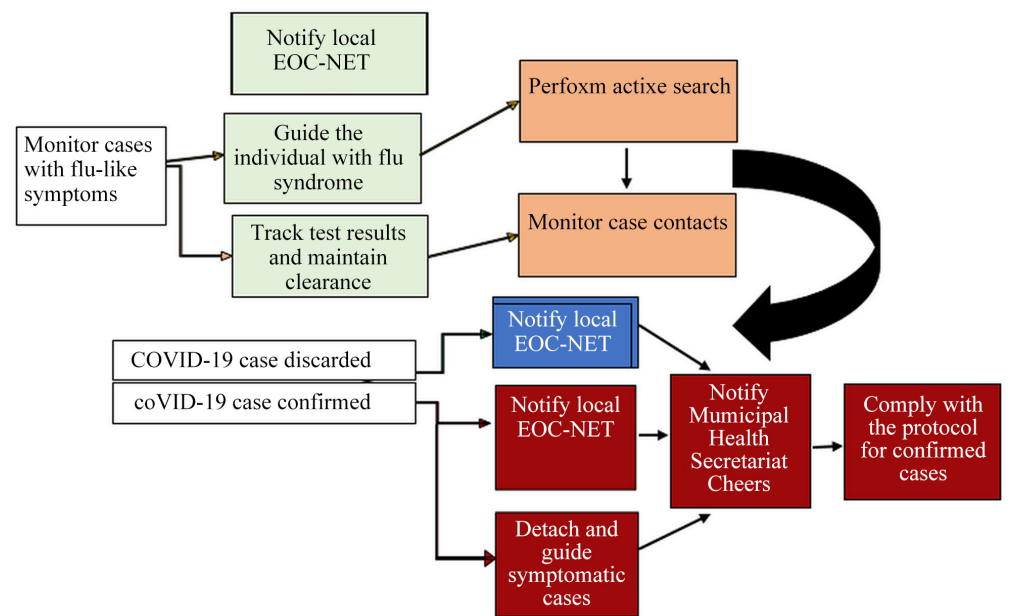

Figure 2. Local monitoring action plan. Template for each educational institution. Source: Own authorship.

Table 1. Norms of the previous phase.

$\checkmark$ Definition of health safety standards for school environments.

$\checkmark$ Diagnosis of the service capacity of the network, conditions for its readjustment, and acquisition of the necessary materials.

$\checkmark$ Definition of the progressivity of the return and dimensioning of the students' rotation alternatives, because of the network conditions and possibilities for their readjustment.

$\checkmark$ The previous definition of the curriculum revision (to be revised based on the diagnostic evaluation of the students when they return) and of the hybrid teaching strategies, aiming at the achievement of the learning and development objectives and the fulfillment of the minimum annual workload; acquisition/adequacy of the necessary means.

$\checkmark$ Allocation of financial resources for training professionals, health adaptations, infrastructure, and technologies;

$\checkmark$ Review of the school calendar. 
Table 2. General protocol.

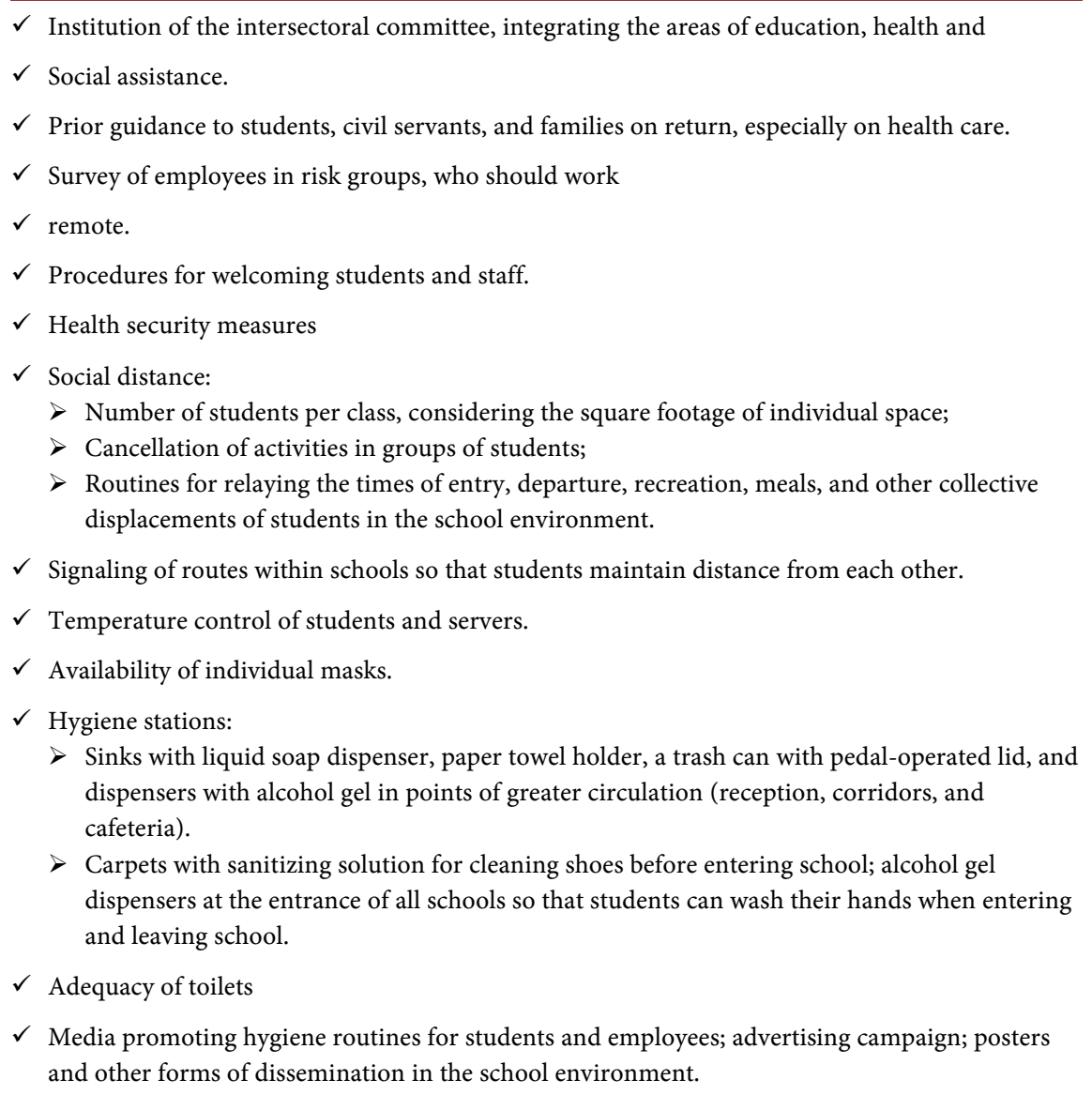

\section{Specific Protocols}

\section{HEALTH}

Table 3 gathers the main protective measures for resuming safe, face-to-face classes about health (WHO \& UNICEF, 2020; ANVISA, 2020; Brasil, 2020).

\section{PEDAGOGICAL}

Table 4 shows the main protective measures for resuming face-to-face classes in relation to the pedagogical proposal (WHO \& UNICEF, 2020; WHO, 2020; Brasil, 2020).

\section{LEGAL}

Table 5 shows the main protective measures for resuming face-to-face classes about the legal proposal (WHO \& UNICEF, 2020; Brasil ( $n^{\circ}$ 1565), 2020; Brasil, 1988).

\section{COMMUNICATION}

Table 6 shows the main protective measures for resuming face-to-face classes about the communication proposal (Brasil, 1990).

\section{MONITORING}

Table 7 shows the main protective measures for resuming face-to-face classes about the monitoring proposal (Van Lancker \& Parolin, 2020; Mangiarotti, Peyre, Zhang, Huc, Roger, \& Kerr, 2020). 
Table 3. Protective measures for health.

$\checkmark$ Organize its operational structure so that its students maintain a distance of $1.0 \mathrm{~m}^{2}$ between them and other people, especially students and teachers, in all classroom activities;

$\checkmark$ Sanitize the educational unit's facilities daily with bleach diluted in 1 tablespoon per liter of water, spraying in all environments, before the arrival of the people involved in the classroom activities;

$\checkmark$ Make 70\% alcohol gel easily accessible in all physical spaces of the educational establishment, especially in classrooms;

$\checkmark$ Guide and promote the hand hygiene of all those who attend on-site educational activities, when entering the educational unit's facilities;

$\checkmark$ Promote and supervise the mandatory use of a cloth mask by all people who attend the educational establishment, especially students, teachers, and other employees;

$\checkmark$ Conduct the temperature measurement of all people who come to the educational establishment, at the time of admission to the educational unit's premises;

$\checkmark$ Promote the immediate isolation of anyone who has the characteristic systems of covid-19, guiding them and their families to carry out the immediate 14-day quarantine procedure at their residence;

$\checkmark$ Notify the existence of confirmed cases of covid-19 to the municipality's health authorities detected in students, teachers, and other collaborators, immediately upon acknowledgment;

$\checkmark$ Promote the demarcation of the physical spaces of the school unit in order to improve measures of social distance;

$\checkmark$ Promote the removal of face-to-face activities, reorganizing them in some of the possible remote modalities, of students and workers who fall into groups at risk for the new coronavirus (COVID-19), among them: I-over 60; II-manageable; III-people who have symptoms related to COVID-19, namely: persistent fever and cough (dry or secretive), runny nose and shortness of breath; IV—bearers of immunodeficiency of any kind; $\mathrm{V}$-transplanted and cardiac patients; VI-carriers of other comorbidities associated with COVID-19;

$\checkmark$ Develop an intense and continuous training routine for students and workers on this health protocol, with special emphasis on the correct use of masks, hand and object hygiene, and respect for safe social distance in the school environment;

$\checkmark$ Develop an intensive and continuous training routine for families on this health protocol, with special emphasis on their collaborative engagement in orienting their families and their co-responsibility in the success of these measures, including the rapid and reliable communication to the educational institution and health authorities in case of any of the symptoms of COVID-19.

$\checkmark$ Recommend students and workers to, as far as possible, bring additional clean shoes for use in the classroom;

$\checkmark$ Recommend to students and workers that, as far as possible, they bring additional cloth masks to be changed every 3 hours of stay in an on-site educational environment;

$\checkmark$ Recommend students and workers to bring their own hand towel, cloth, as far as possible, for use in the educational environment;

$\checkmark$ Provide wet rugs with chlorine solution or equivalent in every way of entering the educational environment;

$\checkmark$ Ensure that the environments within the educational establishment are as airy as possible, especially the classrooms, carrying out the educational activity, whenever possible, in open areas; 
Table 4. Pedagogical proposal.

$\checkmark$ The educational institution should prioritize remote educational work, gradually promoting the adoption of face-to-face educational activities in a safe manner and according to their levels of need

$\checkmark$ Every educational institution should develop a home or remote work plan for students in the at-risk group or for those (or their families) who do not feel comfortable and safe to carry out on-site educational activities at the school unit

$\checkmark$ Every educational institution must develop a remote work plan so that teachers and other employees who are in the risk group of covid-19 can develop their activities

$\checkmark$ Organize the pedagogical work plan for educational activities to be carried out in person, preferably carried out in open places or, in their infeasibility, carried out in such a way as to avoid small spaces

$\checkmark$ Organize the pedagogical plan so that activities that require physical interaction occur without contact between students and preferably without sharing materials

$\checkmark$ Organize the educational activity so that students do not remove their materials from the school environment, avoiding as much as possible their removal and re-entry

Table 5. Legal proposal.

$\checkmark$ To reiterate the recommendations of the present protocol, for each educational institution, in the form of a regulation to be made available to the entire community involved in the educational activity, collecting its knowledge;

$\checkmark$ Having defined the parameters indicated in the pedagogical protocol, item II, it is recommended that they be widely disseminated to all those involved with the construction of an "educational option term" to be subscribed by all the contractor/responsible person;

$\checkmark$ For both the period before the return to face-to-face activities and the return period covered in this protocol, it is recommended that the formatting of the remote work to be eventually developed by the workers be materialized in an addendum to the employment contracts;

$\checkmark$ The private educational activity is widely supervised by numerous bodies, especially the Public Ministries, it is recommended that all educational institutions promote the construction of all safety regulations and protocols recommended here, with the respective science and signature of those involved, before the effective return to face-to-face activities.

Table 6. Communication proposal.

$\checkmark$ Inform families and students about the return schedule and protocols at least seven days in advance.

$\checkmark$ Prioritize customer service through digital channels (phone, application, or online)

$\checkmark$ Produce communication materials for distribution in educational institutions when students arrive, with easy-to-understand explanations about the prevention of COVID-19

Table 7. Monitoring proposal.

$\checkmark$ Do not allow COVID-19 symptomatic people to remain in the educational institution;

$\checkmark$ Guidance to parents or guardians to check the temperature of students before they go to the educational institution and when they return. If the temperature is above $37.5^{\circ} \mathrm{C}$, the recommendation is to stay at home;

$\checkmark$ Recommendation for public and private educational institutions to check people's temperature at each entrance;

$\checkmark$ Professionals and students who are part of the risk group must stay at home and carry out activities remotely, in the first stage of the plan to return to face-to-face activities;

$\checkmark$ Separate a room or area to isolate people who have symptoms in the educational institution until they can return home. 


\section{Results of international studies that support the guidelines of the present} study

Large-scale school closures have been implemented worldwide to stem the spread of COVID-19. However, the impact of the closing and reopening of schools on the dynamics of the epidemic remains with great challenges. Therefore, as scientific support, a study simulated the transmission dynamics of COVID19 using a stochastic model based on individuals, incorporating social contact data of school-age children. Thus, assuming that children $<10$ were half more susceptible to infection than older children and adults, it was estimated that closing schools prevented a similar number of infections (13,842 cases; $95 \% \mathrm{CI}$ : 6290, 23,040) as closures workplaces $(15,813 ; 95 \%$ CI: 9963, 22,617) and social distance measures (7030; 95\% CI: 3118, 11,676). Under assumptions of moderate transmission in the community, it was estimated that the reopening of schools would increase symptomatic disease among high school teachers (an additional $40.7 \%$ should have an asymptomatic infection, 95\% CI: 1.9, 61.1), high school teachers $(37.2 \%, 95 \%$ CI: $4.6,58.1)$ and elementary school teachers $(4.1 \%, 95 \%$ CI: -1.7, 12.0). A hybrid learning approach with classes reduced to half 10 students may be required in high schools, while maintaining small groups of 20 students may be required for elementary schools (Head, Andrejko, Cheng, Collender, Phillips, Boser, Heaney, Hoover, Wu, Northrup, Click, Harrison, Lewnard, \& Remais, 2020).

Another study analyzed the evidence that constitutes well-established scientific data and that can guide intervention policies and practices in the post-pandemic context. The outlets considered more obvious for the post-pandemic period, such as remote education, the use of technologies, and the increase in the workload, although they are being incorporated into the school's daily routine with greater intensity, hardly contain the elements to help in the recovery most affected students. Thus, the most solidly based outlets in the literature include a diagnosis of students as a basis for the resumption of teaching programs. And, after that, robust and promising interventions must be carried out that include structured teaching, the use of appropriate literacy methods, the strategic use of homework, and reading programs. The best use of time is to reduce absences and intensive tutoring programs in small groups (Oliveira, Gomes, Matheus, Barcellos, \& Thais, 2020).

Also, investments in Education must be increased, according to UNESCO, the natural drop-in learning may last for more than a decade if public policies are not created that invest in improvements in infrastructure, technologies, training, methodologies, and salaries, in addition to the reinforcement of school lunches, better use of time, tutoring outside the usual class hours and additional material (UNESCO, 2020). There is a need for an appropriate articulation between distance and face-to-face teaching, given that many in Brazil do not have access to quality computers, cell phones, or the Internet, and a considerable number of teachers needed the training to use digital platforms, insert online activities, 
evaluating students at a distance and producing and inserting material on the platforms that help the student to understand the contents (Dias \& Pinto, 2020).

Besides, in the psychological field, it is notorious to encourage solidarity, resilience and the continuity of social relations between educators and students in this period is fundamental, as it helps to lessen the negative psychological impact of the pandemic on students. Now, it is important to prevent and reduce the high levels of anxiety, depression, and stress that confinement causes in quarantined students (Dias \& Pinto, 2020).

\section{Conclusion}

Therefore, multiple intervention strategies at the school and reductions in transmission in the community, in addition to the extent achieved so far, will be necessary to avoid the excessive undue risk associated with the reopening of the school.

\section{Funding}

The work was supported by Faceres-Medical School, São José do Rio Preto, SP, Brazil.

\section{Conflicts of Interest}

The authors declare no conflicts of interest regarding the publication of this paper.

\section{References}

Agência Nacional de Vigilância Sanitária (ANVISA) (2020). Gerência de Inspeção e Fiscalização Sanitária de Alimentos, Cosméticos e Saneantes. Gerência Geral de Inspeção e Fiscalização Sanitária. Nota Técnica No. 48/2020/SEI/GIALI/GGFIS/DIRE4/ANVISA: documento orientativo para produção segura de alimentos durante a pandemia de Covid-19.

http://portal.anvisa.gov.br/documents/219201/4340788/NOTA_TECNICA_N_48_Bo as_Praticas_e_Covid_19_Revisao_final.pdf/ba26fbe0-a79c-45d7-b8bd-fbd2bfdb2437

Brasil (1988). Presidência da República. Casa Civil. Subchefia para Assuntos Jurídicos. Constituição da República Federativa do Brasil de 1988. http://www.planalto.gov.br/ccivil_03/constituicao/constituicao.htm

Brasil (1990). Presidência da República. Casa Civil. Subchefia para Assuntos Jurídicos. Lei no 8.069, de 13 de julho de 1990. Dispóe sobre o Estatuto da Criança e do Adolescente e dá outras providências. http://www.planalto.gov.br/ccivil_03/leis/18069.htm

Brasil. Ministério da Educação. Conselho Nacional de Educação. Parecer n ${ }^{\circ} 5$ de 2020. Reorganização do Calendário Escolar e da possibilidade de cômputo de atividades não presenciais para fins de cumprimento da carga horária mínima anual, em razão da Pandemia da COVID-19.

http://portal.mec.gov.br/index.php?option=com_docman\&view=download\&alias $=145$ 011-pcp005-20\&category_slug=marco-2020-pdf\&Itemid=30192

Brasil. Ministério da Educação. Gabinete do Ministro. Portaria ${ }^{\circ} 572$, de $1^{\circ}$ de julho de 2020. Institui o Protocolo de Biossegurança para Retorno das Atividades nas Instituiçôes Federais de Ensino e dá outras providências. Diário Oficial da União: Seção 1, Brasília. 
http://pesquisa.in.gov.br/imprensa/jsp/visualiza/index.jsp?data $=02 / 07 / 2020 \&$ jornal $=51$ 5\&pagina $=30$

Brasil. Ministério da Saúde. Gabinete do Ministro. Portaria no 1.565, de 18 de junho de 2020. Estabelece orientações gerais visando à prevenção, ao controle e à mitigação da transmissão da COVID-19, e à promoção da saúde física e mental da população brasileira, de forma a contribuir com as ações para a retomada segura das atividades e o convívio social seguro. Diário Oficial da União: Seção 1, Brasília.

http://www.in.gov.br/en/web/dou/-/portaria-n-1.565-de-18-de-junho-de-2020-262408151

Brasil. Ministério da Saúde. Organização Pan-Americana da Saúde (2010). Biossegurança em saúde: prioridades e estratégias de ação. Brasília: Ministério da Saúde, 242 p. (Série B. Textos Básicos de Saúde).

http://bvsms.saude.gov.br/bvs/publicacoes/biosseguranca_saude_prioridades_estrategi cas_acao.pdf

Brasil. Ministério da Saúde. Secretaria de Atenção Primária à Saúde (SAPS) (2020). Protocolo de manejo clínico do coronavírus (Covid-19) na atenção primária à saúde (versão 9). Brasília: SAPS.

Cheng, S. Y., Wang, C. J., Shen, A. C., \& Chang, S. C. (2020). How to Safely Reopen Colleges and Universities during COVID-19: Experiences from Taiwan. Annals of Internal Medicine, 173, 638-641. https://doi.org/10.7326/M20-2927

Dias, É., \& Pinto, F. C. F. (2020). A Educação e a Covid-19. Ensaio: Avaliação e Políticas Públicas em Educação, 28, 545-554. https://doi.org/10.1590/s0104-40362019002801080001

Head, J. R., Andrejko, K., Cheng, Q., Collender, P. A., Phillips, S., Boser, A., Heaney, A. K., Hoover, C. M., Wu, S. L., Northrup, G. R., Click, K., Harrison, R., Lewnard, J. A., \& Remais, J. V. (2020). The Effect of School Closures and Reopening Strategies on COVID-19 Infection Dynamics in the San Francisco Bay Area: A Cross-Sectional Survey and Modeling Analysis. medRxiv [Preprint]. https://doi.org/10.1101/2020.08.06.20169797

Johns Hopkins University, Center for Teaching and Learning, Johns Hopkins Bloomberg School of Public Health (2020). COVID-19 Contact Tracing Course.

https://www.coursera.org/learn/covid-19-contact-tracing? edocomorp=covid-19-contac t-tracing

Mangiarotti, S., Peyre, M., Zhang, Y., Huc, M., Roger, F., \& Kerr, Y. (2020). Chaos Theory Applied to the Outbreak of COVID-19: An Ancillary Approach to Decision Making in Pandemic Context. Epidemiology \& Infection, 148, e95.

https://doi.org/10.1017/S0950268820000990

Oliveira, J. B. A., Gomes, M., \& Barcellos, T. (2020). A Covid-19 e a volta às aulas: Ouvindo as evidências. Ensaio: Avaliação e Políticas Públicas em Educação, 28, 555-578. https://doi.org/10.1590/s0104-40362020002802885

UNESCO Digital Library Website (2020). Marco de ação e recomendações para a reabertura de escolas. https://unesdoc.unesco.org/ark:/48223/pf0000373348_por

Van Lancker, W., \& Parolin, Z. (2020). COVID-19, School Closures, and Child Poverty: A Social Crisis in the Making. Lancet Public Health, 5, e243-e244.

https://doi.org/10.1016/S2468-2667(20)30084-0

World Health Organization (WHO) (2020). Coronavirus Disease (COVID-19) Pandemic. https://www.who.int/emergencies/diseases/novel-coronavirus2019?gclid=Cj0KCQjw3 Nv3BRC8ARIsAPh8hgKZe3P6ZHdvDTfYCu9EPqfuYhj_rCKWMpHvY5EhvXJ9WMs TMDKOZrYaAuv1EALw_wcB

World Health Organization. WHO \& UNICEF. IFRC (2020). Key Messages and Actions for 
COVID-19 Prevention and Control in Schools.

https://www.who.int/docs/default-source/coronaviruse/key-messages-and-actions-for-co vid19-prevention-and-control-in-schools-march2020.pdf?sfvrsn=baf81d52_4\&gclid=C j0KCQjwoPL2BRDxARIsAEMm9y-yhpkw2N6vL2qCIh6idMeCR7pJkdOP-WrZxsu_U wMbf1xyZcxHUkaAo6YEALw_wcB 